\title{
Incidence and Spatial Distribution of Caribbean Yellow Band Disease in La Parguera, Puerto Rico
}

\author{
Francisco J. Soto-Santiago ${ }^{1,2}$ and Ernesto Weil ${ }^{1}$ \\ ${ }^{1}$ Department of Marine Sciences, University of Puerto Rico, Mayagüez, P.O. Box 9000, San Juan P.R. 00681, Puerto Rico \\ ${ }^{2}$ Department of Environmental Sciences, University of Puerto Rico, Río Piedras Campus, P.O. Box 70377, \\ San Juan P.R. 00936, Puerto Rico
}

Correspondence should be addressed to Francisco J. Soto-Santiago, franciscoj_soto@yahoo.com

Received 31 March 2012; Revised 11 June 2012; Accepted 22 June 2012

Academic Editor: Horst Felbeck

Copyright (c) 2012 F. J. Soto-Santiago and E. Weil. This is an open access article distributed under the Creative Commons Attribution License, which permits unrestricted use, distribution, and reproduction in any medium, provided the original work is properly cited.

The incidence and spatial distribution patterns of Caribbean Yellow Band Disease (CYBD) on the important frame-builder coral Montastraea faveolata were assessed by counting, tagging, and mapping all diseased and healthy colonies for one year in each of three $100 \mathrm{~m}^{2}$ quadrats on two inner, mid-shelf, and shelf-edge reefs off La Parguera, Puerto Rico. Healthy colonies were checked every month from January to December of 2009 to monitor disease spread within each quadrant. Incidence increased significantly from winter $(0.7 \pm 0.8 \% \mathrm{SE})$ to summer $(1.5 \pm 1.1 \% \mathrm{SE}, n=23$, Sign Test; $Z=2.40 ; P=0.01)$. Mid-shelf reefs had the highest host abundance and showed significantly higher CYBD incidence $(2.1 \pm 1.4 \% \mathrm{SE}, n=14)$ compared to the other zones $(H=9.74 ; d f=2 ; P=0.04)$. The increased incidence in the summer suggests that warmer months favor development of CYBD on M. faveolata. Results showed aggregated patterns of CYBD when all colonies (i.e., healthy + diseased) at the spatial scales sampled were analyzed on each reef. This suggests facilitation of disease spread between aggregated colonies within populations. Similar stressful conditions then might trigger the disease in susceptible, aggregated colonies harboring the potential pathogens.

\section{Introduction}

Coral diseases seem to be one of the main causes of the decline of Caribbean coral reefs. Over the last three decades, fast emergence and high virulence of coral reef diseases have produced substantial declines in live coral tissue and colonies [1-9]. The recent increase in diseases in the marine environment has been associated with different stressors such as elevated sea surface temperatures $[3,7,9,10]$ and nutrient enrichment $[11,12]$. Certain coral diseases (particularly tissue-loss diseases) seem to be more prevalent where there is human disturbance [13-15], but not all (e.g., Acropora tumors, [13]). Caribbean Yellow Band Disease (CYBD) is one of the most damaging coral diseases affecting important reef builders in the wider Caribbean $[5,16]$. In Puerto Rico, CYBD is one of the most prevalent, persistent, and detrimental diseases affecting important reef-building species $[8,9,17,18]$. CYBD has shown a high prevalence in near-pristine areas far from anthropogenic disturbance
$[5,18]$. However, very little is known about the incidence and the spatial distribution patterns of this disease.

Spatial distribution patterns describe how organisms are arranged in a particular habitat or community. Spatial patterns can be regular (i.e., uniform distribution), random (i.e., random distribution) or aggregated (i.e., clumped distribution). Patterns of disease infections can be studied by documenting spatial distribution patterns which could help in characterizing the etiology of the disease and identifying potential mechanisms of infection [19]. Clustered or aggregated disease patterns in a population along a reef could mean that the disease is infectious and water borne; the closer the hosts, the faster the rate of infection (incidence) and the higher the number of infected colonies (prevalence). A noninfectious disease should in fact display a Poisson (purely random) distribution within the host population (but of course the host population itself could still display a clumped or regular distribution). Spatial distribution patterns of aspergillosis affecting Gorgonia ventalina were 
highly aggregated and prevalence was high in the Florida Keys [19]. It has been stated that predictive models should be used to study spatial distribution patterns of coral diseases $[20,21]$. Also, coral diseases should be investigated for environmental relationships separately until they are known to have a common cause [21]. Foley et al. [22] showed that M. annularis colonies infected with CYBD were less clustered (i.e., more regular) than were healthy colonies between 10 $30 \mathrm{~m}$ in a shallow back-reef in Akumal Bay, Mexico. Clustered patterns of coral disease occurrence could also result if there are transmitted by a vector and the vector displays a clumped distribution (e.g., Porites trematodiasis, $[14,21]$ ).

Prevalence is the proportion of infected colonies in a population. Thus, higher prevalence might suggest higher susceptibility of host colonies, higher pathogenicity of the disease agent, higher densities of susceptible colonies, or a combination of these [19]. However, not all diseases are necessarily caused by pathogens, they can be in response to many abiotic/biotic triggers [23] and, therefore, pathogen virulence is not universally relevant when discussing coral diseases. Prevalence of CYBD in the Montastraea annularis species complex increased dramatically to $52 \%$ in reefs off the western end of Mona Island [17] and from 1\% to 55\% between 1999 and 2007 in La Parguera, on the southwest coast of Puerto Rico [9]. After the 2005 bleaching event, CYBD prevalence increased $40 \%$ in M. faveolata with high coral mortality attributed to this disease. CYBD, white plague outbreak and bleaching have caused $60 \%$ of damage on some reefs $[9,18]$. Even though CYBD seems to be caused by a group of Vibrio bacteria [24, 25], little is known about the mechanisms of spread of the disease and its pathogenicity of the disease agent. Several experimental attempts in the field and laboratory have failed to demonstrate infectiousness [26], suggesting that the diseased colonies in natural populations should not to be aggregated. None of the previous studies provides information on CYBD incidence on $M$. faveolata populations.

The goals of this study were to assess the spatial and temporal variability in CYBD incidence on M. faveolata, to characterize the spatial distribution patterns of CYBD infected colonies, and to explore the relationship between spatial pattern and incidence of CYBD within and across reefs off La Parguera, Puerto Rico. Results from this study help clarify the etiology and potential mechanisms of infection of CYBD, the rate of infection over time and how the distribution patterns of the population (susceptible colonies) may affect the spread and potential impact of the disease.

\section{Materials and Methods}

Coral reefs in La Parguera Natural Reserve on the southwest coast are considered the best developed reefs of Puerto Rico [18]. A broad insular shelf, moderate water energy, favorable environmental conditions (high temperatures and low rainfall), and low human impact over long periods of time have allowed extensive development of diverse coral reef communities [18]. To assess the CYBD incidence and spatial variability in CYBD diseased and healthy colonies, six reefs

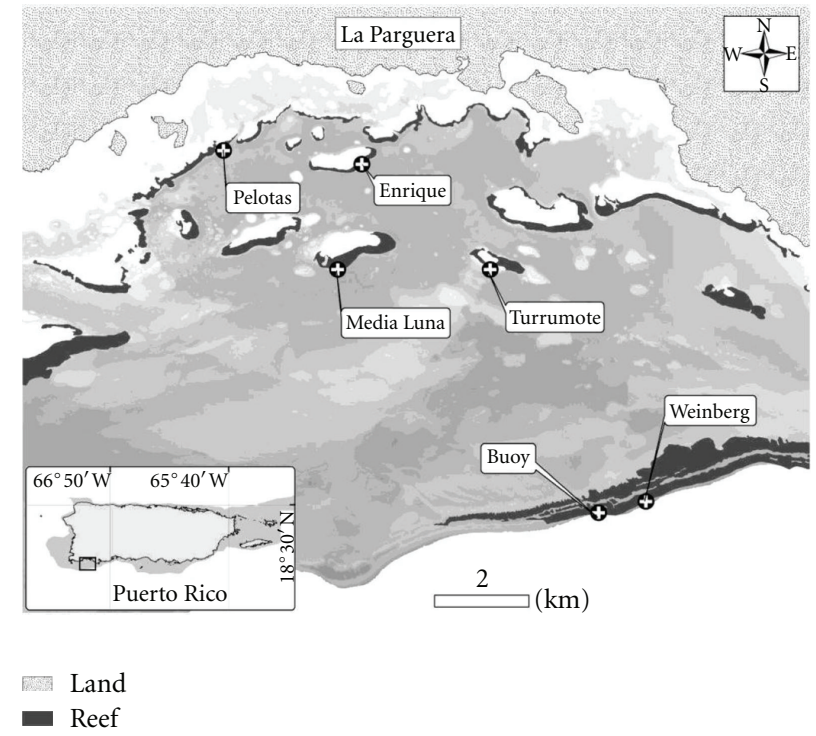

Figure 1: Map of the study sites in La Parguera, Puerto Rico.

were selected on an inshore-offshore gradient: two fringing reefs on the inner-shelf (Pelotas and Enrique), two fringing reefs on the mid-shelf (Media Luna and Turrumote), and two deep bank reefs on the shelf-edge (Weinberg and Buoy) (Table 1, Figure 1).

2.1. Temporal and Spatial Variability of CYBD Incidence in M. Faveolata. Incidence (i.e., proportion of newly infected colonies per month) of CYBD affecting Montastraea faveolata in La Parguera was assessed through winter and summer of 2009. Total incidence per site and season was also calculated. Incidence of CYBD was assessed using three $100 \mathrm{~m}^{2}$ permanently marked areas $\left(300 \mathrm{~m}^{2}\right)$ positioned between $3-9 \mathrm{~m}$ depths and separated by at least $20 \mathrm{~m}$ on each of the fringing reefs, and at a depth of $20 \mathrm{~m}$ on the offshore bank reefs. Each quadrant corner was marked with tagged rebar and, before each survey; the perimeter was marked with measuring tapes. Parallel tape lines were extended every two meters to form five $2 \times 10 \mathrm{~m}$ bands (20 $\mathrm{m}^{2}$ each), and all diseased and healthy colonies of $M$. faveolata were checked, counted, and mapped so the location and status of every single colony within the $100 \mathrm{~m}^{2}$ was known after each survey. Healthy colonies were checked and photographed every month from January to December 2009 to monitor new CYBD infections. Temperature data for the year was obtained from Hobo Pro v.1 and v. 2 temperature loggers that have been deployed on these reefs since 2005 . The loggers record temperature every 2 hours. Disease incidence data (i.e., proportion of newly infected colonies per month) did not meet the assumptions of parametric statistical tests and could not be normalized with arcsine transformations. Differences in incidence between seasons (winter and summer) were therefore, evaluated using Sign Tests. Differences in incidence (median \pm SE) between reef zones and sites were evaluated using nonparametric KruskalWallis tests (Levene's test: $P>0.05$ ). Significant differences 
TABle 1: Characteristics of the study sites in La Parguera, Puerto Rico (modified from [27]).

\begin{tabular}{lccccc}
\hline Zone & Reef & \multicolumn{2}{c}{ Location } & D & $\begin{array}{c}\text { Distance } \\
\text { from shore }(\mathrm{km})\end{array}$ \\
\hline Inner-shelf & Enrique & $17^{\circ} 56.658$ & $67^{\circ} 02.213$ & 1.5 & 1 \\
Inner-shelf & Pelotas & $17^{\circ} 57.442$ & $67^{\circ} 04.176$ & 6 & $1-14$ \\
Mid-shelf & M. Luna & $17^{\circ} 56.093$ & $67^{\circ} 02.931$ & 2 & $4-20$ \\
Mid-shelf & Turrumote & $17^{\circ} 56.097$ & $67^{\circ} 01.130$ & 6 & $2-20$ \\
Shelf-edge & Weinberg & $17^{\circ} 53.429$ & $66^{\circ} 59.320$ & 6 & $18-23$ \\
Shelf-edge & Buoy & $17^{\circ} 53.110$ & $66^{\circ} 59.510$ & 6 & $18-23$ \\
\hline
\end{tabular}

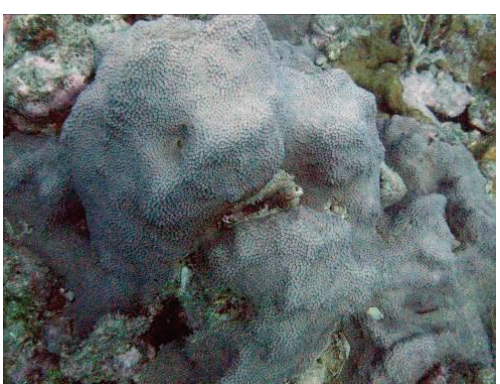

(a)

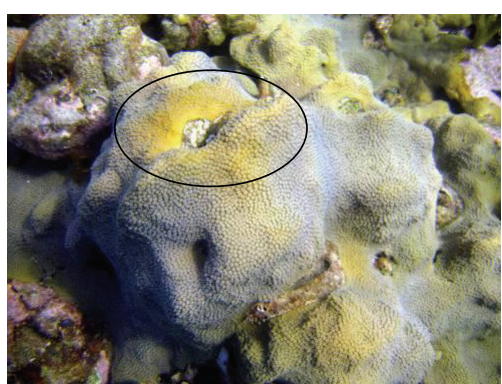

(b)

Figure 2: Photographic time series of a colony at Enrique showing signs of YBD. (a) January 2009; (b) September 2009.

were followed by multiple comparison tests. Statistica 7 software was used to run the analyses.

2.2. Spatial Distribution of CYBD in M. Faveolata. Single colonies were defined and selected as continuous patches of tissue of $M$. faveolata, including isolated patches of tissue showing partial mortality. This was carefully inspected to avoid the inclusion of ramets of a different genet pooled together as a single colony. Spatial distribution patterns were assessed for the whole population and CYBD-infected $M$. faveolata within each of the $100 \mathrm{~m}^{2}$ quadrants on each of the six reefs using the nearest neighbor method [28, 29]. The method is based on comparing the distribution of distances from one individual to its nearest neighbor in space $[28,29]$. This distribution can be defined as

$$
R=\frac{r_{A}}{r_{E}}
$$

where $R$ is the index of aggregation, $r_{A}$ is the mean distance to the nearest neighbor and can be defined as

$$
r_{A}=\frac{\sum r_{i}}{n}
$$

where $r_{i}$ is the distance to nearest neighbor for individual $I$ and $n$ is the number of individuals in the study area; $r_{E}$ is the expected distance to nearest neighbor and can be defined as

$$
r_{E}=\frac{1}{2 \sqrt{ } \rho},
$$

where $\rho$ is the density of organisms (number of organisms/size of the study area).
If the spatial pattern is random, $R=1$, when clumping occurs, $R$ approaches zero and in a regular pattern $R$ increases $>1$. A simple test of significance for deviation from randomness was used, as the standard error of the expected distance is known from plane geometry [29]. This test of significance can be defined as

$$
z=\frac{\left(r_{A}-r_{E}\right)}{S_{r}},
$$

where $z$ is the standard normal deviate and $S_{r}$ is the standard error of the expected distance to the nearest neighbor and can be defined as

$$
S_{r}=\frac{0.26136}{\sqrt{ } n \rho}
$$

\section{Results}

Significant differences in CYBD incidence in $M$. faveolata were foundamong reef sites $(H=12.13 ; d f=4 ; P=0.02)$. Pelotas (an inner-shelf reef) showed no sign of CYBD over the study period. Turrumote and Media Luna (mid-shelf reefs) showed the highest total incidence levels (median \pm SE\%) in the study, each with $2.1 \pm 1.5 \%(n=14)$, followed by Enrique (inner-shelf reef) with $1.5 \pm 1.2 \%(n=5)$. Buoy and Weinberg (shelf-edge reefs) showed the lowest incidence levels in the study with each site showing $0.6 \pm 1.4 \%(n=4)$. Time series photographs of tagged colonies at the different sites showed healthy colonies in the winter developing the CYBD signs during the summer (Figure 2). Disease signs were still visible at December 2009, but no tissue mortality was observed. 


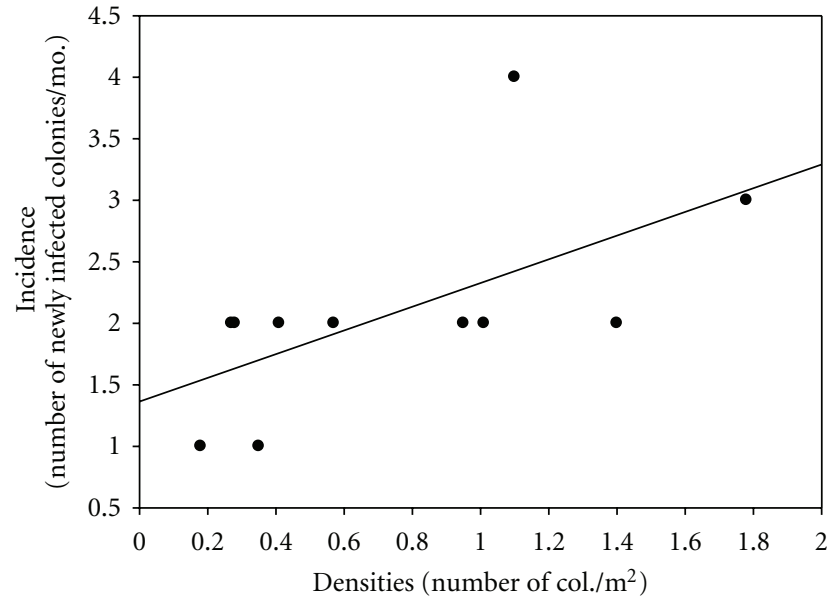

Figure 3: Spearman correlation analysis between densities of $M$. faveolata and incidence of CYBD on the different reefs $(\rho=0.70$; $P=0.01)$.

Proportion of monthly CYBD incidence in M. faveolata was higher on mid-shelf reefs $(0.58$ newly infected colonies/month) than on inner (0.41 newly infected colonies/month) or on shelf-edge reefs $(0.16$ newly infected colonies/month) throughout $2009(H=9.74 ; d f=2 ; P=$ 0.04 ). There was a significant positive correlation (Spearman correlation analysis; $\rho=0.70, P=0.01$ ) between CYBD incidence and densities of $M$. faveolata in each of the three $100 \mathrm{~m}^{2}$ quadrants per site (Figure 3).

CYBD incidence (median \pm SE\%) on $M$. faveolata increased significantly $0.7 \pm 0.8 \%$ to $1.5 \pm 1.1 \%(n=23)$ from winter to summer (Sign Test; $Z=2.40 ; P=0.01$ ). Incidence in $M$. faveolata ranged from 2.00 newly infected colonies/month during the cold season (winter or JanuaryApril) to 3.75 newly infected colonies/month during the warm water season (summer or June-September) of 2009 (Table 2). Monthly average temperatures in 2009 increased from $26.6^{\circ} \mathrm{C}$ in the winter to $29.6^{\circ} \mathrm{C}$ in summer (Figure 4). During February $\left(26.5^{\circ} \mathrm{C}\right)$ and June $2009\left(28.8^{\circ} \mathrm{C}\right)$, CYBD incidence was highest (Table 2). February finished with 3 new colonies infected in Media Luna, 1 in Turrumote and 2 in Buoy. In June, 1 newly infected colony was found in Enrique, 2 in Media Luna and 4 in Turrumote.

Analysis of the spatial distribution patterns of CYBD in $M$. faveolata showed an aggregated pattern for diseased colonies and for all colonies (pooled diseased + healthy) analyzed together. This aggregated pattern was found in all of the $100 \mathrm{~m}^{2}$ areas surveyed (Table 3 ) and was significantly different from randomness (Table 4). There were no CYBDinfected M. faveolata colonies in the $100 \mathrm{~m}^{2}$ areas surveyed in Pelotas (i.e., inner shelf reef) so these were excluded from the analyses.

\section{Discussion}

In La Parguera and on the west coast of Puerto Rico, winter average temperatures used to drop below $25.5^{\circ} \mathrm{C}$. In the last 10 years, however, winter mean temperatures

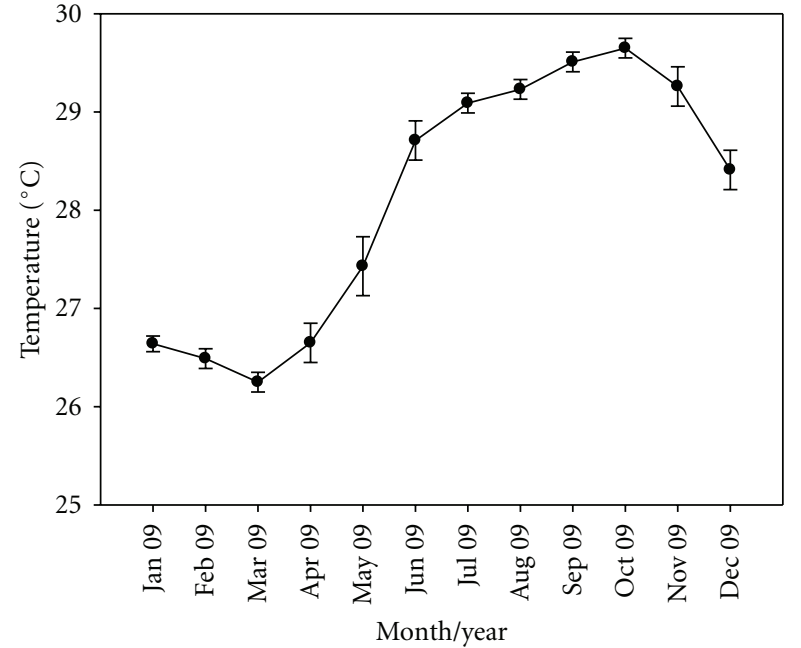

FIGURE 4: Line graph of monthly average $( \pm \mathrm{SD})$ seawater temperatures from January-December 2009 in La Parguera, Puerto Rico.

have not dropped below $26.5^{\circ} \mathrm{C}$ potentially compromising the immune response of corals or increasing virulence of pathogens [3]. In the present study, highest incidence levels were found in June and September (summer). However, high incidence levels were also found in February (winter). $M$. faveolata colonies are more susceptible to any pathogen in the environment due to a weakened state when temperature changes. Susceptibility to opportunistic pathogens increases significantly in corals that are harmed from climatic and physical perturbations [2]. Although previous studies have shown that prevalence of CYBD increases in Montastraea species when temperature increases [3, 30-32], a decrease in temperature may cause harm to these colonies as well. Cold temperatures can be detrimental to corals by causing coral bleaching $[33,34]$. Further research on how low temperatures may trigger coral diseases, in this case CYBD, should provide interesting information on the dynamics of these stressors.

CYBD distribution found in the different reefs through the Caribbean is due to the combination of host population abundance and distribution, presence of potential pathogens and different environmental factors [24, 35], a pattern similar to most infectious diseases. The significant positive correlation between densities of M. faveolata and CYBD incidence found in the present study suggests that this disease is affecting abundant and susceptible hosts mainly at midshelf reefs (i.e., Turrumote and Media Luna). These reefs showed the highest colony densities and CYBD incidence levels compared to inner and shelf-edge reefs. Our results concur with other studies where the number of diseased colonies was positively correlated with the abundance of susceptible species [36, 37].

CYBD infected colonies showed an aggregated pattern in all of the $100 \mathrm{~m}^{2}$ areas surveyed. The same spatial dispersion pattern was found for the whole population (i.e., healthy + diseased) as well. This could mean that $M$. faveolata colonies are harboring at all times the Vibrio pathogens that cause 
TABle 2: Number of newly infected M. faveolata colonies per month in 2009 at the different reef sites. (—): no newly infected colonies. Winter included the months from January-April and summer included the months from June-September.

\begin{tabular}{lcccccccccccc}
\hline & Jan. & Feb. & Mar. & Apr. & May & Jun. & Jul. & Aug. & Sep. & Oct. & Nov. & Dec. \\
\hline Enrique & - & - & - & 2 & - & 1 & - & - & 2 & - & - & - \\
M. Luna & - & 3 & - & - & - & 2 & - & 2 & - & - & - & - \\
Turrumote & - & 1 & - & - & - & 4 & - & - & 2 & - & - & - \\
Buoy & - & 2 & - & - & - & - & - & - & - & - & - & - \\
Weinberg & - & - & - & - & - & - & - & - & 2 & - & - & - \\
\hline
\end{tabular}

TABLE 3: Index of aggregation, $R$ values, with sample size (in parenthesis) for the three $100 \mathrm{~m}^{2}$ quadrants (Q) in the different sites. (-): no data was found. $(*)$ : not significant data.

\begin{tabular}{lcccccc}
\hline \multirow{2}{*}{ Reef } & \multicolumn{2}{c}{ Q 1 } & \multicolumn{2}{c}{ Q 2 } & \multicolumn{2}{c}{ Q 3 } \\
& Healthy + CYBD & CYBD & Healthy + CYBD & CYBD & Healthy + CYBD & CYBD \\
\hline Pelotas & - & - & - & - & - & - \\
Enrique & $*$ & $*$ & $0.63(26)$ & $0.5(2)$ & $0.70(16)$ & $0.48(2)$ \\
Media Luna & $0.55(80)$ & $0.66(15)$ & $0.48(124)$ & $0.7(16)$ & $0.46(150)$ & $0.60(28)$ \\
Turrumote & $0.68(70)$ & $0.86(40)$ & $0.65(61)$ & $0.69(13)$ & $0.58(27)$ & $*$ \\
Buoy & $0.64(11)$ & $*$ & $0.84(14)$ & $*$ & $0.75(36)$ & $0.92(5)$ \\
Weinberg & $0.89(17)$ & $0.84(2)$ & $0.66(20)$ & $1.01(5)$ & $0.66(51)$ & $0.48(6)$ \\
\hline
\end{tabular}

TABle 4: Colony distribution departure from randomness; $z$ and $P$ values (in parenthesis) from the test of significance for the three $100 \mathrm{~m}^{2}$ quadrants in the different sites. (-): no data was found. $(*)$ : not significant data.

\begin{tabular}{lcccccc}
\hline \multirow{2}{*}{ Reef } & \multicolumn{2}{c}{ Q 1 } & \multicolumn{2}{c}{ Q 2 } & \multicolumn{2}{c}{ Q 3 } \\
& Healthy + CYBD & CYBD & Healthy + CYBD & CYBD & Healthy + CYBD & CYBD \\
\hline Pelotas & - & - & - & - & - & - \\
Enrique & $*$ & $*$ & $0.63(26)$ & $0.5(2)$ & $0.70(16)$ & $0.48(2)$ \\
Media Luna & $0.55(80)$ & $0.66(15)$ & $0.48(124)$ & $0.7(16)$ & $0.46(150)$ & $0.60(28)$ \\
Turrumote & $0.68(70)$ & $0.86(40)$ & $0.65(61)$ & $0.69(13)$ & $0.58(27)$ & $*$ \\
Buoy & $0.64(11)$ & $*$ & $0.84(14)$ & $*$ & $0.75(36)$ & $0.92(5)$ \\
Weinberg & $0.89(17)$ & $0.84(2)$ & $0.66(20)$ & $1.01(5)$ & $0.66(51)$ & $0.48(6)$ \\
\hline
\end{tabular}

CYBD, and that these trigger the disease when colonies are more vulnerable due to temperature changes such as those that occur in the summer or during warmer winters. Further research in the bacterial strains within M. faveolata tissues may help to find if these colonies are harboring the Vibrio consortium that is associated to CYBD. Foley et al. [22], studying spatial dispersion patterns of CYBD in Montastraea annularis in Akumal, Mexico, found contrasting results. They found that CYBD-affected colonies showed a more regular (less clustered) spatial pattern compared to the whole population (healthy + diseased) and concluded that proximity to other $M$. annularis may offer protection from CYBD perhaps in the form of barriers to disease agents or genetic resistance of some coral colonies. Foley et al. [22] defined subcolonies of $M$. annularis "as distinct lobes of aggregated clonal corallites that form a recognizable unit of a main corallum (boulder)." It is imperative to carefully inspect this aspect of the analysis due to a high probability of confusion and error if one selects ramets of a different genet pooled as a single colony. In our study, CYBD-infected M. faveolata showed highly aggregated spatial patterns (similar to the whole population) in all reefs in La Parguera. Distribution patterns depend on habitat characteristics, substrate availability, and current regimes. Differences in species distribution and spatial scale used can explain the contrasting results between our study and the one from Foley et al. [22]. In our study, we used a spatial scale of $100 \mathrm{~m}^{2}$ quadrants, but Foley et al. [22] studied a spatial scale between $10-30 \mathrm{~m}$. Spatial patterns can change at different scales of observation and this is highly important when studying spatial distribution patterns of coral diseases [22]. Jolles et al. [19] found that clusters of infected G. ventalina were larger than expected under the direct contact hypothesis. It is important to recognize that prevalence (proportion of infected colonies in a population) is not the same epidemiological measure as incidence (new cases of diseased colonies over time). However, both parameters can indicate the level at which a disease is affecting a population. Incidence indicates the risk of contracting the disease, whereas prevalence indicates how extensive the disease is. Although we did not assess CYBD prevalence in the $100 \mathrm{~m}^{2}$ quadrants on each site, prevalence from other areas in these 
same sites during 2009 showed a similar pattern to the incidence data we gathered by having more infected colonies in mid-shelf reefs where host abundances were higher (SotoSantiago and Weil, in preparation). Some of the index of aggregation data showed a low sample size (Table 3). This could have affected the patterns of aggregation since lower number of colonies may result in less power when applying the nearest neighbor method. However, we only included in the analysis data that showed significant differences from randomness (Tables 3 and 4).

If the pattern of warmer winters continues spreading worldwide, this could be highly detrimental to coral reefs around the world. Furthermore, all the ecosystem services that these reefs provide can be lost in the near future. By having warmer winters, corals will not be able to adapt to temperature regimes and susceptibility to any pathogens in the surrounding environment will affect more dramatically these organisms. It will be more difficult for corals to recover from diseases and bleaching as they will be vulnerable all year long. Coral diseases have shown associations to different environmental variables at different spatial scales [21]. Although baseline spatiotemporal assessments such as the study presented here are useful, ultimately this information needs to be combined with covarying environmental measurements over long time periods with high spatial replication and the results coupled and investigated for relationships using predictive modeling and other spatial analyses. Our results have shown that the study of incidence and spatial distribution patterns can highlight important information on the etiology and potential mechanisms of CYBD affecting important reef framework species such as $M$. faveolata. These types of studies can elucidate the dynamics of spread and infection of emerging coral diseases which are threatening to wipe out coral reefs and its ecosystem services in Puerto Rico and the wider Caribbean.

\section{Acknowledgments}

Funding for this project was provided by NOAA-CRES grant no. NA170P2919, the GEF-World Bank Coral Reef Targeted Research and Capacity Building Project through the Coral Disease Group, and the Department of Marine Sciences, University of Puerto Rico. Thanks to Jorge Casillas, Emmanuel Irizarry, and employees of the Department of Marine Sciences, University of Puerto Rico for help in the field and support with logistics. Thanks to Michael Nemeth for providing the map of the study sites. Brian Bingham and three anonymous reviewers provided critical comments to improve this manuscript.

\section{References}

[1] T. J. Goreau, J. Cervino, M. Goreau et al., "Rapid spread of diseases in Caribbean coral reefs," Revista de Biologia Tropical, vol. 46, supplement 5, pp. 157-171, 1998.

[2] L. L. Richardson, "Coral diseases: what is really known?" Trends in Ecology and Evolution, vol. 13, no. 11, pp. 438-443, 1998.

[3] D. Harvell, S. Altizer, I. M. Cattadori, L. Harrington, and E. Weil, "Climate change and wildlife diseases: when does the host matter the most?" Ecology, vol. 90, no. 4, pp. 912-920, 2009.

[4] E. P. Green and A. W. Bruckner, "The significance of coral disease epizootiology for coral reef conservation," Biological Conservation, vol. 96, no. 3, pp. 347-361, 2000.

[5] E. Weil, I. Urreiztieta, and J. Garzón-Ferreira, "Geographic variability in the incidence of coral and octocoral diseases in the wider Caribbean," in Proceedings of the 9th International Coral Reef Symposium, vol. 2, pp. 1231-1238, 2002.

[6] E. Weil, "Coral reef diseases in the wider Caribbean," in Coral Health and Disease, E. Rosenberg and Y. Loya, Eds., pp. 35-68, Springer, New York, NY, USA, 2004.

[7] J. Miller, R. Waara, E. Muller, and C. S. Rogers, "Coral bleaching and disease combine to cause extensive mortality on reefs in US Virgin Islands," Coral Reefs, vol. 25, no. 3, p. 418, 2006.

[8] A. W. Bruckner and R. L. Hill, "Ten years of change to coral communities off Mona and Desecheo Islands, Puerto Rico, from disease and bleaching," Diseases of Aquatic Organisms, vol. 87, no. 1-2, pp. 19-31, 2009.

[9] E. Weil, A. Croquer, and I. Urreiztieta, "Temporal variability and impact of coral diseases and bleaching in La Parguera, Puerto Rico from 2003-2007," Caribbean Journal of Science, vol. 45, no. 2-3, pp. 221-246, 2009.

[10] C. D. Harvell, E. Jordán-Dahlgren, S. Merkel et al., "Coral diseases, environmental drivers, and the balance between coral and microbial associates," Oceanography, vol. 20, no. 1, pp. 36$59,2007$.

[11] J. F. Bruno, L. E. Petes, C. D. Harvell, and A. Hettinger, "Nutrient enrichment can increase the severity of coral diseases," Ecology Letters, vol. 6, no. 12, pp. 1056-1061, 2003.

[12] J. D. Voss and L. L. Richardson, "Nutrient enrichment enhances black band disease progression in corals," Coral Reefs, vol. 25, no. 4, pp. 569-576, 2006.

[13] G. S. Aeby, G. J. Williams, E. C. Franklin et al., "Growth anomalies on the coral genera Acropora and Porites are strongly associated with host density and human population size across the Indo-Pacific," PLoS ONE, vol. 6, no. 2, Article ID e16887, 2011.

[14] G. S. Aeby, G. J. Williams, E. C. Franklin et al., "Patterns of coral disease across the Hawaiian Archipelago: relating disease to environment," PLoS ONE, vol. 6, no. 5, Article ID e20370, 2011.

[15] E. A. Dinsdale, O. Pantos, S. Smriga et al., "Microbial ecology of four coral atolls in the Northern Line Islands," PLoS ONE, vol. 3, no. 2, Article ID e1584, 2008.

[16] E. Weil, G. Smith, and D. L. Gil-Agudelo, "Status and progress in coral reef disease research," Diseases of Aquatic Organisms, vol. 69, no. 1, pp. 1-7, 2006.

[17] A. W. Bruckner and R. J. Bruckner, "Consequences of yellow band disease (YBD) on Montastraea annularis (species complex) populations on remote reefs off Mona Island, Puerto Rico," Diseases of Aquatic Organisms, vol. 69, no. 1, pp. 67-73, 2006.

[18] D. L. Ballantine, R. S. Appeldoorn, and P. Yoshioka, "Biology and ecology of puerto rican coral reefs," in Coral Reefs of the USA, B. M. Riegl and R. E. Dodge, Eds., chapter 9, pp. 375406, 2008.

[19] A. E. Jolles, P. Sullivan, A. P. Alker, and C. D. Harvell, "Disease transmission of aspergillosis in sea fans: inferring process from spatial pattern," Ecology, vol. 83, no. 9, pp. 2373-2378, 2002.

[20] S. H. Sokolow, P. Foley, J. E. Foley, A. Hastings, and L. L. Richardson, "Disease dynamics in marine metapopulations: modelling infectious diseases on coral reefs," Journal of Applied Ecology, vol. 46, no. 3, pp. 621-631, 2009. 
[21] G. J. Williams, G. S. Aeby, R. O. M. Cowie, and S. K. Davy, "Predictive modeling of coral disease distribution within a reef system," PLoS ONE, vol. 5, no. 2, Article ID e9264, 2010.

[22] J. E. Foley, S. H. Sokolow, E. Girvetz, C. W. Foley, and P. Foley, "Spatial epidemiology of Caribbean yellow band syndrome in Montastrea spp. coral in the eastern Yucatan, Mexico," Hydrobiologia, vol. 548, no. 1, pp. 33-40, 2005.

[23] T. M. Work, L. L. Richardson, T. L. Reynolds, and B. L. Willis, "Biomedical and veterinary science can increase our understanding of coral disease," Journal of Experimental Marine Biology and Ecology, vol. 362, no. 2, pp. 63-70, 2008.

[24] J. M. Cervino, R. Hayes, T. J. Goreau, and G. W. Smith, “Zooxanthellae regulation in yellow blotch/band and other coral diseases contrasted with temperature related bleaching: In Situ destruction vs expulsion," Symbiosis, vol. 37, no. 1-3, pp. 63$85,2004$.

[25] J. M. Cervino, R. L. Hayes, S. W. Polson et al., "Relationship of Vibrio species infection and elevated temperatures to yellow blotch/band disease in caribbean corals," Applied and Environmental Microbiology, vol. 70, no. 11, pp. 6855-6864, 2004.

[26] E. . Weil, G. W. Smith, K. B. Ritchie, and A. Croquer, "Inoculation of Vibrio spp. onto Montastraea faveolata fragments to determine potential pathogenicity," in Proceedings of 11th International Coral Reef Symposium Session, vol. 7, pp. 202205, Ft. Lauderdale, Fla, USA, 2009.

[27] K. Flynn and E. Weil, "Variability of aspergillosis in Gorgonia ventalina in La Parguera, Puerto Rico," Caribbean Journal of Science, vol. 45, no. 2-3, pp. 215-220, 2009.

[28] P. J. Clark and F. C. Evans, "Distance to nearest neighbor as a measure of spatial relationships in populations," Ecology, vol. 35, pp. 445-453, 1954.

[29] C. J. Krebs, Ecological Methodology, Addison-Wesley, Reading, Mass, USA, 2nd edition, 1999.

[30] E. Weil, A. Croquer, and I. Urreiztieta, “Temporal variability and impact of coral diseases and bleaching in La Parguera, Puerto Rico from 2003-2007," Caribbean Journal of Science, vol. 45, no. 2-3, pp. 221-246, 2009.

[31] J. M. Cervino, F. L. Thompson, B. Gomez-Gil et al., "The Vibrio core group induces yellow band disease in Caribbean and Indo-Pacific reef-building corals," Journal of Applied Microbiology, vol. 105, no. 5, pp. 1658-1671, 2008.

[32] A. W. Bruckner and R. L. Hill, "Ten years of change to coral communities off Mona and Desecheo Islands, Puerto Rico, from disease and bleaching," Diseases of Aquatic Organisms, vol. 87, no. 1-2, pp. 19-31, 2009.

[33] T. Saxby, W. C. Dennison, and O. Hoegh-Guldberg, "Photosynthetic responses of the coral Montipora digitata to cold temperature stress," Marine Ecology Progress Series, vol. 248, pp. 85-97, 2003.

[34] T. C. LaJeunesse, H. Reyes-Bonilla, and M. E. Warner, "Spring "bleaching" among Pocillopora in the Sea of Cortez, Eastern Pacific," Coral Reefs, vol. 26, no. 2, pp. 265-270, 2007.

[35] E. Weil and A. Cróquer, "Spatial variability in distribution and prevalence of Caribbean scleractinian coral and octocoral diseases. I. Community-level analysis," Diseases of Aquatic Organisms, vol. 83, no. 3, pp. 195-208, 2009.

[36] J. L. Borger and S. C. C. Steiner, "The spatial and temporal dynamics of coral diseases in Dominica, West Indies," Bulletin of Marine Science, vol. 77, no. 1, pp. 137-154, 2005.

[37] J. L. Borger, "Dark spot syndrome: a scleractinian coral disease or a general stress response?" Coral Reefs, vol. 24, no. 1, pp. 139-144, 2005. 

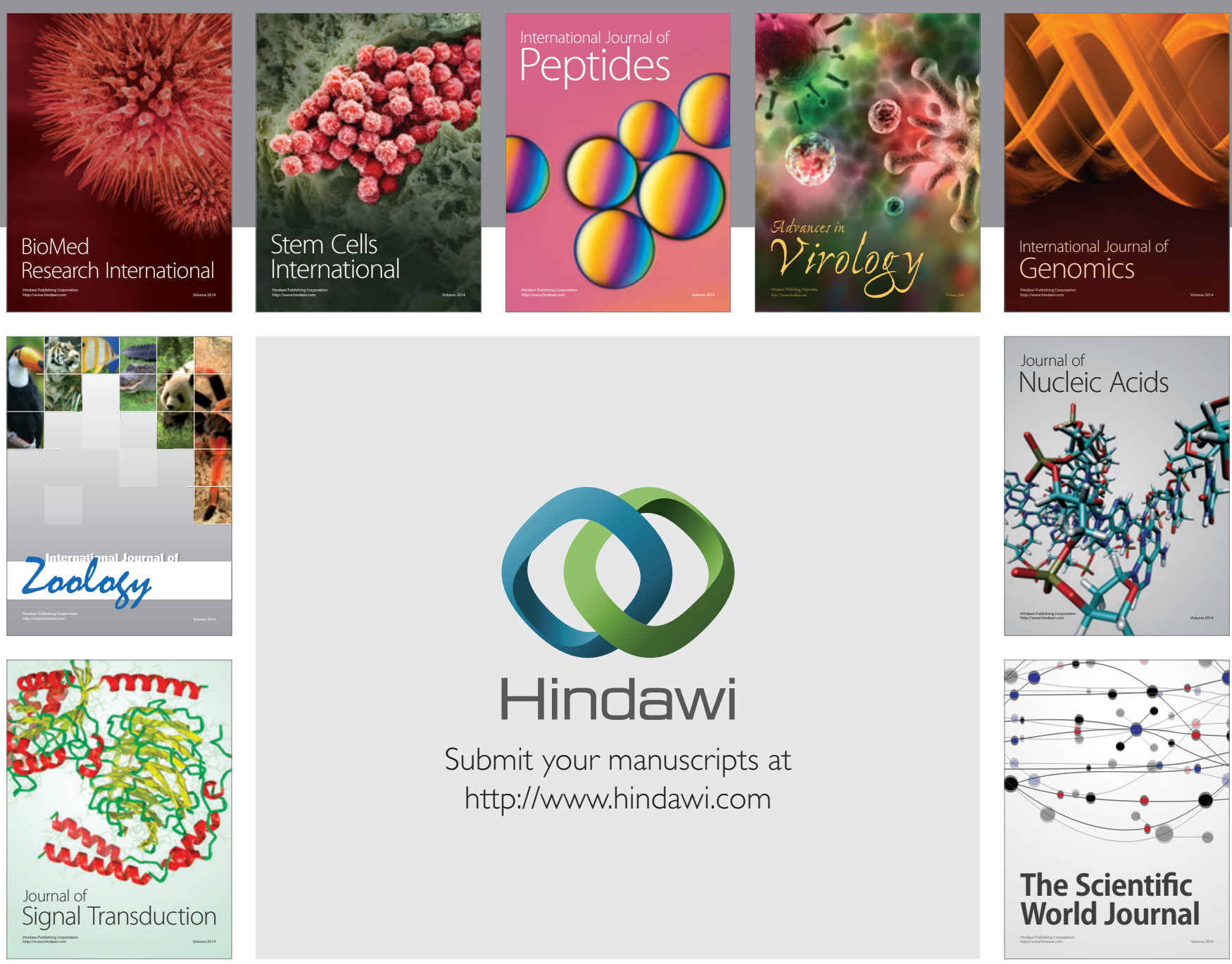

Submit your manuscripts at

http://www.hindawi.com
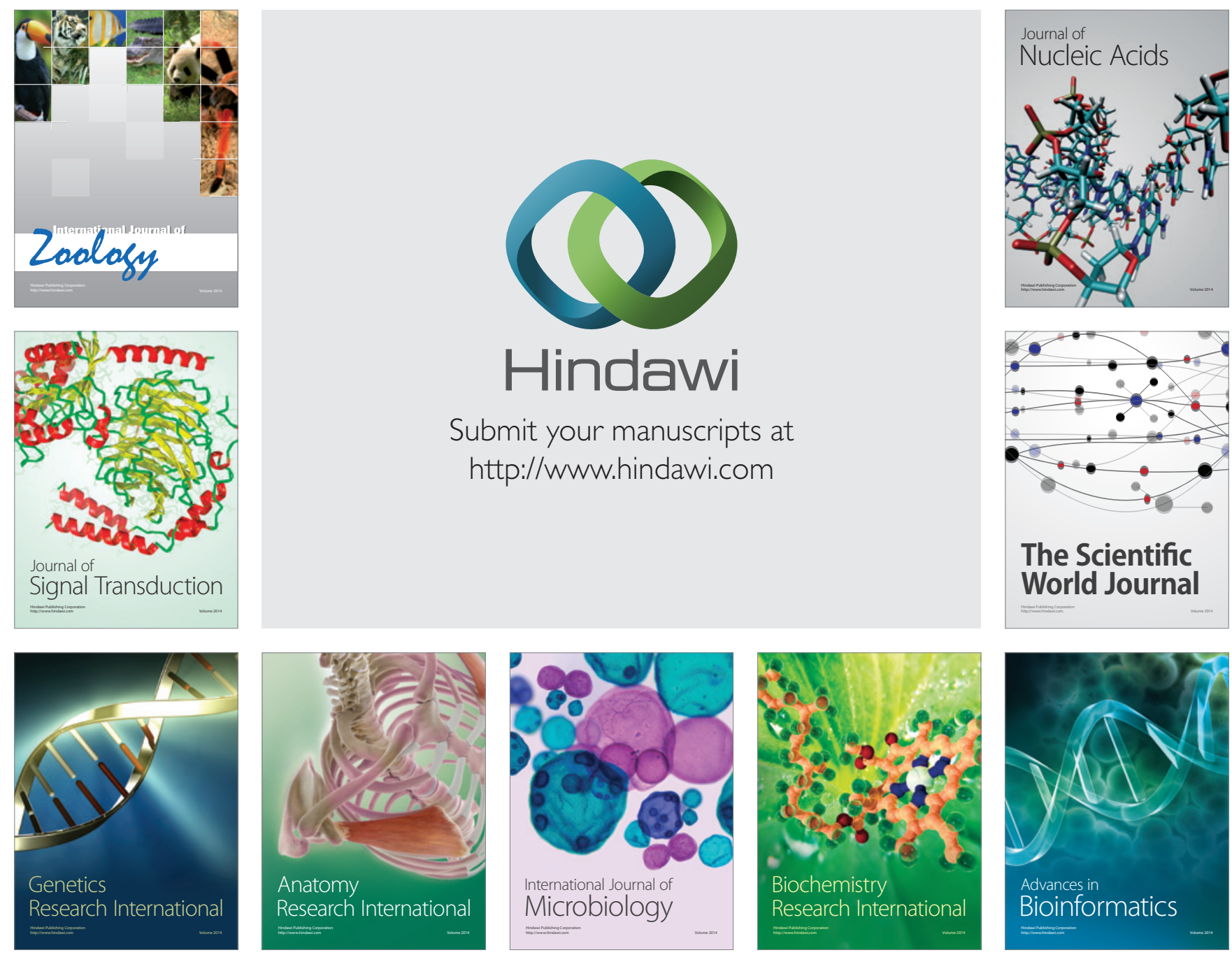

The Scientific World Journal
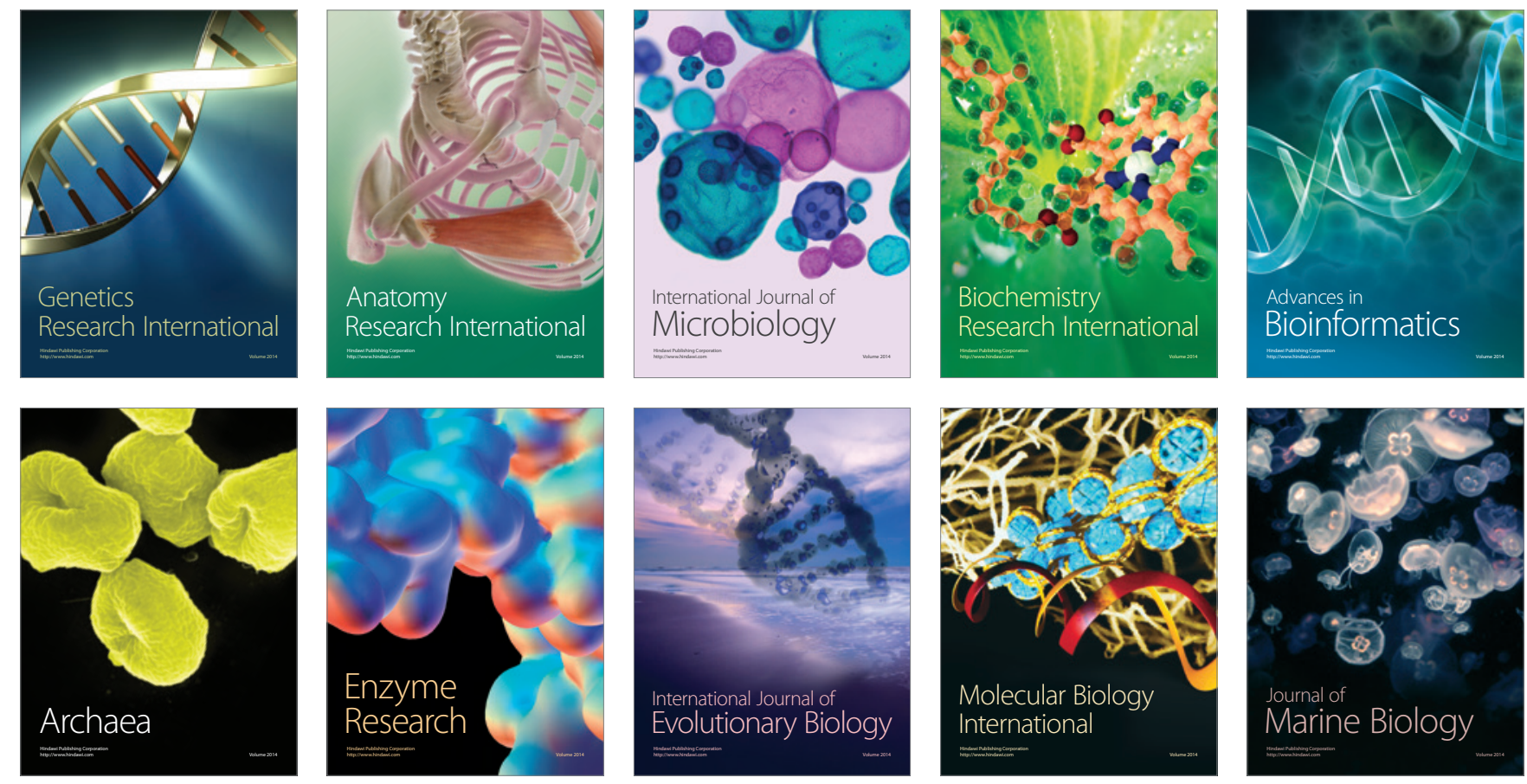